\title{
Effect of age and plant spacing on the energy properties of black wattle
}

\author{
Elder Eloy'*, Dimas Agostinho da Silva², Braulio Otomar Caron', \\ Rômulo Trevisan', Rafaelo Balbinot ${ }^{1}$ \\ ' Federal University of Santa Maria, Frederico Westphalen, RS, BR \\ ${ }^{2}$ Federal University of Paraná, Curitiba, PR, BR \\ Corresponding author, e-mail: eloyelder@yahoo.com.br
}

\begin{abstract}
The aim of this study was to determine the effect on the energy properties of different biomass components of Acacia mearnsii De Wild distributed in different plant spacings: $2.0 \times 1.0 \mathrm{~m}$, $2.0 \times 1.5 \mathrm{~m}, 3.0 \times 1.0 \mathrm{~m}$ and $3.0 \times 1.5 \mathrm{~m}$, in the $1^{\text {st }}, 3^{\text {rd }}$ and $5^{\text {th }}$ years after planting. The experiment was performed in a complete randomized block design in three replicates. The following traits were determined: biomass (BIO), gross calorific value (GCV), basic density (BD), energy productivity (EP), energy density (ED), fixed carbon content (FCC), volatile material content (VMC) and ash content (AC) of different biomass components: wood, bark, branch and leaf. The effect of age significantly influenced all variables, providing an increasing distribution of BIO, EP, BD and ED. The four plant spacings provided different yields of BIO, EP, GCV and BD and the increased spacing caused a tendency to reduce BIO and EP values in all evaluated periods. In the $5^{\text {th }}$ year, even being influenced by the spacing, the BD did not present a systematic increase or decrease over the provided living space. The three components of the trees induced a significant effect on the BIO, GCV, EP, FCC, VMC and AC variables.
\end{abstract}

Keywords: Acacia mearnsii De Wild, immediate chemical analysis, biomass, basic density

\section{Introduction}

The production of forest biomass for energy purposes plays a fundamental role in terms of strategies linked to the production and use of energy, and its consumption is evident for this purpose and this activity has been increasing continuously over the last decade in Brazil. This raw material has an important position in the energy scenario and as a renewable natural resource with a sustainable production and no polluting character when compared with other fossil sources, connect the energy supply with the environmental and economic balance (Eloy et al., 2016).

Acacia mearnsii is a species of great economic importance in the south of the country (Oliveira et al., 2006) and is the main source of bark for the world industry of vegetal tannins used mainly in the tanning industry. The wood presents quality for energy, cellulose and paper production, being resistant to frost (Caron et al., 2011), with a gross calorific value (GCV) around $4482 \mathrm{kcal} \mathrm{kg}^{-1}$ (Silva et al. 2012). Regarding area, black wattle is the third most cultivated species in the state of Rio Grande do Sul after Eucalyptus and Pinus (Sanquetta et al., 2014).

The combination of combustible materials, for example the forest biomass as an energy resource, should be based on the knowledge of its GCV, which is one of the most 
important characteristics. Likewise, in order to assess the wood quality and define its best use, it is essential to identify the physical and mechanical properties which change the final product. The basic density represents the concentration of mass by the volume of wood, being the result of a complex combination of its internal constituents (Trevisan et al., 2007; Mattos et al., 2011). It is directly related to the anatomical structure and chemical composition, causing possible changes in the mechanical resistance, dimensional stability and quality of the machined surface (Lopes et al., 2011).

Plant spacing and cutting age are related. In other words, cultivations with higher population density, usually require thinning or shorter cycles of cutting, since competition among plants occurs earlier, anticipating stagnation of population growth (Caron et al., 2015, Eloy et al., 2015a). Thus, it influences plant growth rates, cutting age, wood quality, as well as silvicultural practices and, consequently, production costs (Inove et al., 2011; Leles et al., $2011)$.

Therefore, it is important to study age and plant spacing regarding the energy production from the biomass. Likewise, there is no relevant data in the literature about the energy potential of Acacia mearnsii.

In this context, the present study aims at determining the influence of age and plant spacing on energy properties in different biomass components of Acacia mearnsii De Wild.

\section{Materials e Methods}

Study area characterization

The experiment was performed at the Federal University of Santa Maria (UFSM), at $27^{\circ} 22$ "S; $53^{\circ} 25^{\prime \prime W}$, at $480 \mathrm{~m}$ of altitude, in Frederico Westphalen, RS.

According to Köppen classification, the predominant climate of the region is Cfa, characterized as subtemperate subhumid, with an annual average temperature of $18.8^{\circ} \mathrm{C}$ and average temperature of the coldest month of $13.3^{\circ} \mathrm{C}$.

The experiment was performed with a complete randomized block design, characterized by a $3 \times 4 \times 4$ factorial, with three periods (1st, 3rd and 5th years after planting), four plant spacings $(2.0 \times 1.0 \mathrm{~m}, 2.0 \times 1.5 \mathrm{~m}, 3.0 \times 1.0$ and $3.0 \times 1.5 \mathrm{~m}$ ) and four tree components (wood, bark, branch and leaf) in three replicates. The block contemplates 16 experimental units, each one with 45 plants distributed in 5 planting lines.

The predominant soil in the experimental area is a typical dystrophic Red Latosol. Plowing and harvesting operations were performed before the manual planting in September 2008.

\section{Sampling}

The destructive evaluations in the trees were carried out in the first year (2009), the third year (2011) and the fifth year (2013) after planting, in which 36 trees were evaluated per period. From these, six discs with approximately $2 \mathrm{~cm}$ thick were removed from the following positions: 0\% (base), $1.30 \mathrm{~m}$ (diameter at breast height - DBH), $25 \%, 50 \% 75 \%$ and $100 \%$ of the total height of the tree, and two symmetrically opposite wedges of each disk were sectioned.

The samples of branches and leaves were collected in the lower, middle and upper stratum of the treetop to obtain an homogeneous material that represented the whole extension of it. The samples were identified and taken to air circulation oven to obtain the dry matter. The samples of wood, bark, leaf and branch were dried at $103^{\circ} \mathrm{C}$ until constant weight to determine the moisture content.

\section{Assessments}

The direct method was used to determine the biomass (BIO), which consisted of the felling and weighing of the different components of the trees (Sanquetta, 2002). The total fresh masses of the trees were determined in field and from each component, samples were taken to obtain their moisture content in the laboratory.

In the determination of the gross calorific value (GCV) and the immediate chemical analysis (ICA), the materials obtained in the sampling were used, being milled in a knife mill with a 40 mesh sieve, aiming at obtaining a thinner and uniform material. The GCV evaluations were performed using a digital calorimeter pump, model C5000 Cooling System, IKA Werke, with adiabatic principle according to the technical 
norm NBR 8633 (ABNT, 1984) and for the ICA, the technical norm NBR 8112 (ABNT, 1986), in which volatile material, ash and fixed carbon contents were obtained.

The materials obtained in the sampling were used to determine the basic density (BD). The procedures were performed according to the technical standard NBR 11941 (ABNT, 2003).

In the determination of the energy productivity (EP), BIO values were multiplied by their respective GCV, according to the following expression:

\section{$\mathrm{EP}=\mathrm{BIO} * \mathrm{GCV}$}

In which: EP = Energy productivity (Gcal $\mathrm{ha}^{-1}$ ); $\mathrm{BIO}=$ dry biomass of each component (ton $\mathrm{ha}^{-1}$ ) and GCV = Gross calorific value $\left(\mathrm{kcal} \mathrm{kg}^{-1}\right)$.

To determine the energy density (ED), the values of BD and GCV were multiplied, according to the following expression:

\section{$\mathrm{DE}=\mathrm{BD} * \mathrm{GCV}$}

In which: $E D=$ energy density $\left(\mathrm{kcal} \mathrm{m}^{-3}\right)$; $\mathrm{BD}=$ basic density of the wood over the tree volume $\left(\mathrm{kg} \mathrm{m}^{-3}\right)$ and $\mathrm{GCV}=$ gross calorific value of the wood $\left(\mathrm{kcal} \mathrm{kg}^{-1}\right)$.

\section{Data Analysis}

Data were submitted to statistical analysis in which it was performed the analysis of variance, $\mathrm{F}$ test and Tukey test at $5 \%$ probability. The assumptions of the analysis of variance were achieved and the Bartlett test was performed to verify the homogeneity of the variances. The Tukey's test was performed when the null hypothesis was rejected.

\section{Results and Discussion}

The analysis of variance revealed a significant difference for all variables among the three ages (1, 3 and 5 years) and among the four components of the trees: wood, bark, branch and leaf. This characteristic was also observed among the four plant spacings for the variables $\mathrm{BIO}, \mathrm{EP}, \mathrm{GCV}$ and BD.

It was observed a difference between year $x$ component for all variables analyzed. For spacing $x$ component, this characteristic is reported only for BIO, EP and GCV. For year $x$ spacing $x$ component, this characteristic was reported only for $\mathrm{BIO}$ and $\mathrm{GCV}$.
In the first year of evaluation, the production of $\mathrm{BIO}$ and EP showed no significant difference among the different component of the trees. For GCV, the leaf presented the highest mean value, which was $5194 \mathrm{kcal} \mathrm{kg}^{-1}$ in the largest plant spacing. In the same way, for FCC and AC, the bark component was different from the others and the mean values for wood reached $23.91 \%$ and $1.67 \%$, respectively, for the same variables. On the other hand, the bark showed the lowest values of VMC, motivated mainly by the high values of FCC and AC. For wood, mean values reached $75.83 \%$ (Table 1).

In the analysis of $\mathrm{BIO}$ in the different component of the trees over the four plant spacings, there was a relation between the density of planting with the distribution of each component. In other words, in the treatments with higher densities, the highest values of $\mathrm{BIO}$ were observed when compared to the less dense spacings. For Caron et al. (2015), there is a greater biomass production per unit of area in the smaller spacings, mainly due to the greater number of individuals. This characteristic was also observed for EP in different plant spacing.

In the $3^{\text {rd }}$ year of evaluation, the highest $\mathrm{BIO}$ values were observed in the wood component at the smallest plant spacing, followed by the branch componentat the largest spacing. Likewise, this characteristic was observed for EP in the same component. The highest mean values for GCV were reported for the leaf component, which reached $5393 \mathrm{kcal} \mathrm{kg}^{-1}$. However, in general, the wood presented the lowest GCV for all spacings. Similarly, BD and ED varied among spacings with the highest means of $0.466 \mathrm{~g} \mathrm{~cm}^{-3}$ and $1.990 \mathrm{Gcal} \mathrm{m}^{-3}$ respectively (Table 2 ).

In the $5^{\text {th }}$ year of evaluation, the production of $\mathrm{BIO}$ and $\mathrm{EP}$ of wood were statistically different and superior to the other component. As in the previous two periods, in the $5^{\text {th }}$ year of evaluation the highest mean for GCV was observed in the leaf component, which reached $5245 \mathrm{kcal} \mathrm{kg}^{-1}$. For the wood, in a general way, the smallest mean values of this variable are reported (Table 3).

It was observed that the four planting spacings led to different BIO production and EP of the four different component of the shoot part 
Table 1. Test of means for biomass (BIO) in ton $\mathrm{ha}^{-1}$, energy productivity (EP) in $\mathrm{Gcal} \mathrm{ha}^{-1}$, gross calorific value (GCV) in $\mathrm{kcal} \mathrm{kg}^{-1}$, fixed carbon content (FCC) in \%, volatile materials content (VMC) in \%, ash content (AC) in \%, basic density (BD) in $\mathrm{cm}^{-3}$ and energy denstity (ED) in $\mathrm{Gcal} \mathrm{m}^{-3}$, for the different component (comp.) of Acacia mearnsii trees distributed in different plant spacings in the first year after planting.

\begin{tabular}{|c|c|c|c|c|c|}
\hline \multirow{2}{*}{ Variable } & \multirow{2}{*}{ Comp. } & \multicolumn{4}{|c|}{ Plant Spacing (m) } \\
\hline & & $2.0 \times 1,0$ & $2,0 \times 1,5$ & $3,0 \times 1,0$ & $3,0 \times 1,5$ \\
\hline \multirow{5}{*}{$\mathrm{BIO}$} & Wood & $2.118 \mathrm{aA}$ & $1.080 \mathrm{aAB}$ & $0.804 a A B$ & $0.643 \mathrm{aB}$ \\
\hline & Bark & $0.548 \mathrm{aA}$ & $0.232 \mathrm{aA}$ & $0.195 \mathrm{aA}$ & $0.088 \mathrm{aA}$ \\
\hline & Branch & $1.351 \mathrm{aA}$ & $0.885 \mathrm{aA}$ & $0.652 \mathrm{aA}$ & $0.451 \mathrm{aA}$ \\
\hline & Leaf & $1.155 \mathrm{aA}$ & $0.919 \mathrm{aA}$ & $1.038 \mathrm{aA}$ & $0.779 \mathrm{aA}$ \\
\hline & Total & $5.172 \mathrm{~A}$ & $3.116 \mathrm{~A}$ & $2.689 \mathrm{~A}$ & $1.961 \mathrm{~A}$ \\
\hline \multirow{4}{*}{ EP } & Wood & $9.669 \mathrm{aA}$ & $4.931 \mathrm{aA}$ & $3.619 \mathrm{aA}$ & $2.881 \mathrm{aA}$ \\
\hline & Bark & $2.676 \mathrm{aA}$ & $1.128 \mathrm{aA}$ & $0.935 \mathrm{aA}$ & $0.422 \mathrm{aA}$ \\
\hline & Branch & $6.143 \mathrm{aA}$ & $4.112 \mathrm{aA}$ & $2.997 \mathrm{aA}$ & $2.117 \mathrm{aA}$ \\
\hline & Leaf & $5.954 \mathrm{aA}$ & $4.751 \mathrm{aA}$ & $5.336 \mathrm{aA}$ & $4.047 \mathrm{aA}$ \\
\hline \multirow{4}{*}{ GCV } & Wood & $4565 \mathrm{cA}$ & $4566 \mathrm{cA}$ & $4501 \mathrm{cA}$ & $4481 \mathrm{CA}$ \\
\hline & Bark & $4884 \mathrm{bA}$ & $4857 \mathrm{bA}$ & $4791 \mathrm{bA}$ & $4797 \mathrm{bA}$ \\
\hline & Branch & $4547 \mathrm{CB}$ & $4646 \mathrm{CAB}$ & $4597 \mathrm{CAB}$ & $4694 \mathrm{bA}$ \\
\hline & Leaf & $5155 \mathrm{aA}$ & $5170 \mathrm{aA}$ & $5141 \mathrm{aA}$ & $5194 \mathrm{aA}$ \\
\hline \multirow{4}{*}{ FCC } & Wood & $22.59 \mathrm{~b}$ & $23.84 \mathrm{~b}$ & $23.91 \mathrm{~b}$ & $22.5 \mathrm{~b}$ \\
\hline & Bark & $44.19 a$ & $40.00 \mathrm{a}$ & $42.81 \mathrm{a}$ & $41.70 \mathrm{a}$ \\
\hline & Branch & $18.92 b$ & $19.26 \mathrm{bc}$ & $18.93 \mathrm{C}$ & $18.54 \mathrm{~b}$ \\
\hline & Leaf & $18.89 \mathrm{~b}$ & $18.54 \mathrm{C}$ & $18.14 \mathrm{C}$ & $21.34 \mathrm{~b}$ \\
\hline \multirow{4}{*}{ VMC } & Wood & $75.76 a$ & $74.87 a$ & $74.84 \mathrm{a}$ & $75.83 \mathrm{a}$ \\
\hline & Bark & $50.95 \mathrm{~b}$ & $54.55 \mathrm{~b}$ & $52.11 \mathrm{~b}$ & $52.92 \mathrm{~b}$ \\
\hline & Branch & $78.75 a$ & $78.24 a$ & $78.44 a$ & $79.69 \mathrm{a}$ \\
\hline & Leaf & $77.77 a$ & $78.54 a$ & $78.75 a$ & $75.88 a$ \\
\hline \multirow{4}{*}{$A C$} & Wood & $1.64 \mathrm{C}$ & $1.28 \mathrm{C}$ & $1.25 \mathrm{c}$ & $1.67 \mathrm{c}$ \\
\hline & Bark & $4.86 \mathrm{a}$ & $5.44 a$ & $5.07 \mathrm{a}$ & $5.38 a$ \\
\hline & Branch & $2.32 \mathrm{c}$ & $2.49 \mathrm{~b}$ & $2.63 \mathrm{~b}$ & $1.76 \mathrm{C}$ \\
\hline & Leaf & $3.34 \mathrm{~b}$ & $2.91 \mathrm{~b}$ & $3.11 \mathrm{~b}$ & $2.79 \mathrm{~b}$ \\
\hline$B D$ & Wood & $0.415 \mathrm{~A}$ & $0.402 \mathrm{~A}$ & $0.406 \mathrm{~A}$ & $0.405 \mathrm{~A}$ \\
\hline ED & Wood & 1.896 & 1.822 & 1.826 & 1.816 \\
\hline
\end{tabular}

Means followed by lower case letters in the column do not differ among species; Means followed by the same capital letter in the line do not differ among plant spacing at $5 \%$ probability according to Tukey's test.

of the trees in the three periods after planting. It also happened for GCV and BD in the different years after planting.

For FCC, the highest mean values for the bark component are reported, and the lowest values were observed in the wood component. In contrast, for $\mathrm{VMC}$, the highest mean values were reported in the wood component and the lowest values were presented in the bark component. The highest values of AC were observed in the bark and leaf component, which reached $3.96 \%$ and $4.38 \%$, respectively. And the lowest mean values were related for the wood.

In general, the highest biomass production in the different component present the following order wood> branch> leaf> bark (Table 3). Similar results were observed with Eucalyptus spp. by Caron et al. (2015).

In general, it can be observed that the biomass production significantly decreases in the different component of the plants over the increase of the useful area (plant spacing). On the other hand, it is worth mentioning that over time the amount of wood stored in a given site tends to equalize in different spacings. In the denser plantings the growth stagnation occurs at younger ages and in the plantings with spacing, the stagnation of growth occurs at more advanced ages (Caron et al., 2015).

The results are corroborated by authors who have developed studies related to the influence of density and age of planting on forest production. Among these, we can mention the ones developed by Eloy et al. (2016). Other authors, such as Ladeira et al. (2001) found a difference in the distribution of $\mathrm{BIO}$ among different species and for the same species due to factors such as plant spacing, population age and site quality. 
Table 2. Test of means for biomass (BIO) in ton $\mathrm{ha}^{-1}$, energy productivity (EP) in $\mathrm{Gcal} \mathrm{ha}^{-1}$, gross calorific value (GCV) in $\mathrm{kcal} \mathrm{kg}^{-1}$, fixed carbon content (FCC) in \%, volatile materials content (VMC) in \%, ash content (AC) in \%, basic density (BD) in $\mathrm{cm}^{-3}$ and energy density (ED) in Gcal m $\mathrm{m}^{-3}$ for the different compartments (comp.) of Acacia mearnsii trees distributed in different plant spacings in the third year after planting.

\begin{tabular}{|c|c|c|c|c|c|}
\hline \multirow{2}{*}{ Variable } & \multirow{2}{*}{ Comp. } & \multicolumn{4}{|c|}{ Plant Spacing (m) } \\
\hline & & $2.0 \times 1.0$ & $2.0 \times 1.5$ & $3.0 \times 1.0$ & $3.0 \times 1.5$ \\
\hline \multirow{5}{*}{$\mathrm{BIO}$} & Wood & $45.000 \mathrm{aA}$ & $24.584 a B$ & $17.740 \mathrm{aC}$ & $7.293 \mathrm{bD}$ \\
\hline & Bark & $14.200 \mathrm{cA}$ & $7.035 \mathrm{~dB}$ & $3.310 \mathrm{cC}$ & $2.191 \mathrm{CD}$ \\
\hline & Branch & $28.139 \mathrm{bA}$ & $21.733 \mathrm{bB}$ & $19.440 \mathrm{aC}$ & $13.502 \mathrm{aD}$ \\
\hline & Leaf & $10.799 \mathrm{dA}$ & $9.545 \mathrm{cB}$ & $9.259 \mathrm{~b} \mathrm{~B}$ & 3.437 c C \\
\hline & Total & $98.138 \mathrm{~A}$ & $62.897 \mathrm{~B}$ & $49.749 \mathrm{C}$ & $26.423 \mathrm{D}$ \\
\hline \multirow{4}{*}{ EP } & Wood & $192.690 \mathrm{aA}$ & $105.662 \mathrm{aB}$ & $75.768 \mathrm{bC}$ & $31.134 \mathrm{bD}$ \\
\hline & Bark & $67.464 \mathrm{CA}$ & $31.742 \mathrm{~dB}$ & $15.137 \mathrm{dC}$ & $9.949 \mathrm{dD}$ \\
\hline & Branch & $130.199 \mathrm{bA}$ & $95.712 \mathrm{bB}$ & $86.527 \mathrm{aC}$ & $61.272 \mathrm{aD}$ \\
\hline & Leaf & $56.997 \mathrm{dA}$ & $48.431 \mathrm{CB}$ & $49.350 \mathrm{CB}$ & $18.536 \mathrm{cC}$ \\
\hline \multirow{4}{*}{ GCV } & Wood & $4282 \mathrm{cA}$ & $4298 \mathrm{cA}$ & $4271 \mathrm{cA}$ & $4269 \mathrm{cA}$ \\
\hline & Bark & $4751 \mathrm{bA}$ & $4512 \mathrm{bA}$ & $4573 \mathrm{bA}$ & $4541 \mathrm{bA}$ \\
\hline & Branch & $4627 \mathrm{cA}$ & $4404 \mathrm{bB}$ & $4451 \mathrm{bB}$ & $4538 \mathrm{bAB}$ \\
\hline & Leaf & $5278 \mathrm{aAB}$ & $5074 \mathrm{aB}$ & $5330 \mathrm{aA}$ & 5393 aA \\
\hline \multirow{4}{*}{ FCC } & Wood & $17.23 \mathrm{~b}$ & $16.14 \mathrm{~b}$ & $15.90 \mathrm{~b}$ & $17.40 \mathrm{a}$ \\
\hline & Bark & $30.22 \mathrm{a}$ & $30.43 a$ & $20.05 a b$ & $16.60 \mathrm{a}$ \\
\hline & Branch & $22.43 \mathrm{~b}$ & $16.37 \mathrm{~b}$ & 18.48 b & $15.47 \mathrm{a}$ \\
\hline & Leaf & $21.53 \mathrm{~b}$ & $19.00 \mathrm{~b}$ & $24.10 \mathrm{a}$ & $18.88 \mathrm{a}$ \\
\hline \multirow{4}{*}{ VMC } & Wood & $82.06 \mathrm{a}$ & $83.33 \mathrm{a}$ & $83.40 \mathrm{a}$ & $81.67 \mathrm{a}$ \\
\hline & Bark & $66.82 \mathrm{C}$ & $67.24 \mathrm{~b}$ & $76.30 \mathrm{bc}$ & $81.40 \mathrm{a}$ \\
\hline & Branch & $75.18 b$ & $82.14 \mathrm{a}$ & $79.63 \mathrm{ab}$ & $82.75 a$ \\
\hline & Leaf & $75.99 \mathrm{~b}$ & $78.30 \mathrm{a}$ & $73.23 c$ & $78.19 \mathrm{a}$ \\
\hline \multirow{4}{*}{$A C$} & Wood & $0.71 \mathrm{~b}$ & $0.53 c$ & $0.70 \mathrm{c}$ & $0.93 \mathrm{c}$ \\
\hline & Bark & $2.96 \mathrm{a}$ & $2.33 a b$ & $3.65 a$ & $2.03 \mathrm{~b}$ \\
\hline & Branch & $2.38 a$ & 1.49 b & $1.89 \mathrm{~b}$ & $1.78 \mathrm{~b}$ \\
\hline & Leaf & $2.70 \mathrm{a}$ & $3.05 a$ & $3.16 \mathrm{a}$ & $2.99 \mathrm{a}$ \\
\hline$B D$ & Wood & $0.445 \mathrm{AB}$ & $0.418 \mathrm{~B}$ & $0.466 \mathrm{~A}$ & $0.447 \mathrm{AB}$ \\
\hline ED & Wood & 1.905 & 1.796 & 1.990 & 1.908 \\
\hline
\end{tabular}

Means followed by lower case letters in the column do not differ among species; Means followed by the same capital letter in the line do not differ among plant spacings at $5 \%$ probability according to Tukey's test.

When the population density increases, the total biomass per unit area also increases and the total biomass production per individual decreases. However, there is an increase in the allocation of photoassimilates in the trunk (Schumacher et al., 2011). Economically, these studies are of great importance, since it is possible to save on the cost of implantation, harvesting and transportation of wood in the larger spacings.

The mean values of GCV found for Acacia mearnsii are satisfactory due to cropping periods and local conditions. These values are in accordance with energy efficiency and are within the range of studies performed by Quirino et al. (2005) in a literature review of wood GCV from 258 exotic and native tropical forest species, reported that GCV values were around $4710 \mathrm{kcal}$ $\mathrm{kg}^{-1}$, ranging from 3831 to $5324 \mathrm{kcal} \mathrm{kg}^{-1}$.

Evaluating the effect of age on GCV of Schizolobium amazonicum wood, Vidaurre et al.

(2012) mentioned a negative relation with age. In other words, the younger age presented the highest GCV value with a tendency to decrease with increasing age of the tree. Factors related to the structural composition of wood positively influence its energy potential, especially regarding chemical and elemental constitution (Eloy et al., 2014).

The analysis of EP per unit area allows a better visualization of the energy potential of the crop. Thus, Lima et al. (2011), in Guarapuava$P R$, with Eucalyptus benthamii arranged in the spacing $3.0 \times 2.0 \mathrm{~m}$, reported an estimated energy productivity of $1940 \mathrm{Gcal} \mathrm{ha}^{-1}$ at six years.

Although a significant difference between the three periods is observed, when FCC, VMC and AC of the different components of the trees were analyzed, in general, it is observed a systematic variation of these contents over time, except for the leaf components which showed the opposite trend. 
Table 3. Test of means for biomass (BIO) in ton $\mathrm{ha}^{-1}$, energy productivity (EP) in Gcal ha ${ }^{-1}$, gross calorific value (GCV) in $\mathrm{kcal} \mathrm{kg}^{-1}$, fixed carbon content (FCC) in \%, volatile materials content (VMC) in \%, ash content (AC) in \%, basic density (BD) in $\mathrm{cm}^{-3}$ and energy denstity (ED) in Gcal m${ }^{-3}$ for the different component (comp.) of Acacia mearnsii trees distributed in different plant spacings in the fifth year after planting.

\begin{tabular}{|c|c|c|c|c|c|}
\hline \multirow{2}{*}{ Variable } & \multirow{2}{*}{ Comp. } & \multicolumn{4}{|c|}{ Plant Spacing (m) } \\
\hline & & $2,0 \times 1,0$ & $2,0 \times 1,5$ & $3,0 \times 1,0$ & $3,0 \times 1,5$ \\
\hline \multirow{5}{*}{$\mathrm{BIO}$} & Wood & $143,111 \mathrm{aA}$ & $79,935 \mathrm{aB}$ & $46,690 \mathrm{aC}$ & $55,032 \mathrm{aC}$ \\
\hline & Bark & $10,565 \mathrm{dA}$ & $4,870 \mathrm{~dB}$ & $3,325 \mathrm{dD}$ & $4,172 d C$ \\
\hline & Branch & $60,690 \mathrm{bA}$ & $24,449 \mathrm{bC}$ & $34,155 \mathrm{bB}$ & $14,031 \mathrm{bD}$ \\
\hline & Leaf & $24,951 \mathrm{CA}$ & $10,224 \mathrm{CB}$ & $8,964 \mathrm{CB}$ & 6,547 cC \\
\hline & Total & $239,317 \mathrm{~A}$ & $119,478 \mathrm{~B}$ & $93,134 \mathrm{C}$ & $79,782 \mathrm{C}$ \\
\hline \multirow{4}{*}{ EP } & Wood & 631,406 aA & $355,151 \mathrm{aB}$ & $202,495 \mathrm{aD}$ & $241,921 \mathrm{aC}$ \\
\hline & Bark & $48,081 \mathrm{dA}$ & $20,503 \mathrm{~dB}$ & $14,989 \mathrm{dC}$ & $18,816 \mathrm{dBC}$ \\
\hline & Branch & $270,010 \mathrm{bA}$ & $111,830 \mathrm{bC}$ & $154,415 \mathrm{bB}$ & $62,957 \mathrm{bD}$ \\
\hline & Leaf & $130,768 \mathrm{cA}$ & $53,625 \mathrm{CB}$ & $45,725 \mathrm{cC}$ & $33,756 \mathrm{cD}$ \\
\hline \multirow{4}{*}{ GCV } & Wood & $4412 \mathrm{cA}$ & $4443 \mathrm{bA}$ & $4337 \mathrm{cA}$ & $4396 \mathrm{bA}$ \\
\hline & Bark & $4551 \mathrm{bA}$ & $4210 \mathrm{bA}$ & $4508 \mathrm{bA}$ & $4510 \mathrm{bA}$ \\
\hline & Branch & $4449 \mathrm{bcB}$ & $4574 \mathrm{bA}$ & $4521 \mathrm{bAB}$ & $4487 \mathrm{bAB}$ \\
\hline & Leaf & $5241 \mathrm{aA}$ & $5245 \mathrm{aA}$ & $5101 \mathrm{aA}$ & $5156 \mathrm{aA}$ \\
\hline \multirow{4}{*}{ FCC } & Wood & $18,84 \mathrm{C}$ & $17,93 \mathrm{c}$ & $18,60 \mathrm{c}$ & $18,74 \mathrm{C}$ \\
\hline & Bark & $31,53 a$ & 31,16 a & $30,9 a$ & $31,93 a$ \\
\hline & Branch & $22,84 \mathrm{bc}$ & $21,95 \mathrm{bc}$ & $22,24 \mathrm{bc}$ & $22,10 \mathrm{~b}$ \\
\hline & Leaf & $24,72 \mathrm{~b}$ & $23,97 \mathrm{~b}$ & $23,41 \mathrm{~b}$ & $21,68 \mathrm{bc}$ \\
\hline \multirow{4}{*}{ VMC } & Wood & $80,57 \mathrm{a}$ & $81,48 \mathrm{a}$ & $80,66 \mathrm{a}$ & $80,59 \mathrm{a}$ \\
\hline & Bark & $64,91 \mathrm{C}$ & $65,13 \mathrm{C}$ & $65,14 \mathrm{C}$ & $64,24 \mathrm{C}$ \\
\hline & Branch & $75,60 \mathrm{~b}$ & $76,17 \mathrm{~b}$ & $75,95 \mathrm{ab}$ & $76,30 \mathrm{ab}$ \\
\hline & Leaf & $71,28 \mathrm{~b}$ & $72,04 \mathrm{~b}$ & $72,21 \mathrm{~b}$ & $74,12 \mathrm{~b}$ \\
\hline \multirow{4}{*}{$A C$} & Wood & $0,59 \mathrm{c}$ & $0,59 \mathrm{c}$ & $0,73 \mathrm{c}$ & $0,67 \mathrm{c}$ \\
\hline & Bark & $3,56 a$ & $3,71 \mathrm{a}$ & $3,96 a$ & $3,84 a$ \\
\hline & Branch & $1,57 \mathrm{~b}$ & $1,89 \mathrm{~b}$ & $1,80 \mathrm{~b}$ & $1,60 \mathrm{~b}$ \\
\hline & Leaf & $4,00 a$ & $3,99 \mathrm{a}$ & $4,38 \mathrm{a}$ & $4,20 a$ \\
\hline $\mathrm{BD}$ & Wood & $0,565 \mathrm{~A}$ & $0,500 \mathrm{~B}$ & $0,524 \mathrm{~B}$ & $0,566 \mathrm{~A}$ \\
\hline ED & Wood & 2,492 & 2,221 & 2,273 & 2,488 \\
\hline
\end{tabular}

According to Silva et al. (2015), fuels with high FCC content have a slower burning, which is positive for the process as it implies a longer residence time in the firing appliances in comparison to others that have lower FCC.

In general, the AC and FCC of the bark were higher than wood ones, different than what happened to VM content (Table 1, 2 and 3). Similar results for the three levels were found by Vale et al. (2002) who studied 47 forest species and observed a variation of the VM content of the wood from 74.62 to $81.20 \%$, and for bark from 65.2 to $76.95 \%$.

Regarding the VMC content, it is reported that it interferes positively in the ignition, because the higher its value, the greater the reactivity, determining how easy a biomass burns. With a high VMC content, it is easier for the biomass to ignite and burn and, although the combustion process is fast, it is difficult to control, reducing the residence time of the fuel inside the combustion apparatus, being able to contribute for low energy efficiency (Eloy et al., 2015b).

Woods with higher FCC contents presented higher BD. Thus, BD and FCC can be used as indicators of wood for direct combustion. Regardless the material used, FCC is related to GCV. Therefore, what is expected is that high levels of FCC imply a higher GCV.

The results of BD of the wood observed in this study are within the range that Quirino et al. (2005) reported for 108 forest species, ranging from 0.200 to $1.080 \mathrm{~g} \mathrm{~cm}^{-3}$. The different plant spacings induce the variation of the $\mathrm{BD}$ of the wood in the 5th year after planting and it was not verified a systematic variation of increase or decrease in relation to the living space provided by the spacing.

Differences in the effect of spacing between plants and BD have been reported 
in the literature. Trevisan et al. (2012) did not find a significant effect of spacing between plants, with the BD of wood. However, they are divergent from those reported by Roque and Ledzema (2003) who verified an increase in BD with increasing spacing.

It was observed that BD increases over the evaluated periods. For Eloy et al. (2014), the causes of these divergences can be attributed to several factors, such as the genetic variability, different environmental conditions, according to different ages.

\section{Conclusion}

The three ages significantly influenced all the analyzed variables, providing an increasing distribution of the variables biomass, energy productivity, basic density and energy density.

The four plant spacings provided different biomass production, energy yield, gross calorific value and basic density. The increase in spacing causes a tendency of reduction of biomass values and energy yield in all evaluated periods.

Despite being influenced by the spacing, the basic density of the 5th year did not show a systematic variation of increase or decrease over the provided living space.

The four components of the trees induced a significant effect on the biomass, gross calorific value, energy productivity, fixed carbon content, volatile material content and ash content.

The best relation age $x$ spacing $x$ component for energy production of Acacia mearnsii was verified in the fifth year after planting, in the $2.0 \times 1.0 \mathrm{~m}$ spacing, in the wood component.

\section{Acknowledgements}

The Coordination of Improvement of Higher Education Personnel (CAPES) and the National Council for Scientific and Technological Development (CNPq), for granting the master's and doctoral scholarship, respectively, to the first author.

\section{References}

ABNT. Associação Brasileira de Normas Técnicas. 2003. NBR 11941: Determinação da densidade básica da madeira. ABNT, Rio de Janeiro, Brasil. $6 \mathrm{p}$.
ABNT. Associação Brasileira de Normas Técnicas. 1986. NBR 8112 : carvão vegetal: análise imediata. ABNT, Rio de Janeiro, Brasil. 6 p.

ABNT. Associação Brasileira de Normas Técnicas. 1984. NBR 8633: carvão vegetal: Determinação do poder calorífico superior. ABNT, Rio de Janeiro, Brasil. 6 p.

Caron, B.O., Souza, V.Q., Eloy, E., Behling, A., Schmidt, D., Trevisan, R. 2011 . Resistência inicial de quatro espécies arbóreas em diferentes espaçamentos após ocorrência de geadas. Ciência Rural 41 (5): 817-822.

Caron, B.O., Eloy, E., Souza, V.Q., Schmidt, D., Balbinot, R., Behling, A., Monteiro, G.C. 2015. Quantificação da biomassa florestal em plantios de curta rotação com diferentes espaçamentos. Comunicata Scientiae 6(1): 106-112.

Eloy, E., Caron, B.O., Silva, D.A., Schmidt, D., Trevisan, R., Behling, A., Elli, E. F. 2014. Influência do espaçamento nas características energéticas de espécies arbóreas em plantios de curta rotação. Revista Árvore 38: 551-559.

Eloy, E., Caron, B.O., Silva, D.A., Souza, V.Q., Trevisan, R., Behling, A., Elli, E.F. 2015 a. Produtividade energética de espécies florestais em plantios de curta rotação. Ciência Rural 45(8): 1424-1431.

Eloy, E., Silva, D.A., Caron, B.O., Elli, E.F. 2016. Effect of age and plant spacing effect of age and plant spacing of Mimosa Scabrella benth. Australian Journal of Basic and Applied Sciences 10(4): 34-42.

Eloy, E., Silva, D.A., Caron, B.O., Souza, V.Q. 2015 b. Capacidade energética da madeira e da casca de acácia-negra em diferentes espaçamentos. Pesquisa Florestal Brasileira 35(82): 163-167.

Inove, M.T., Filho, A.F., Lima, R. 2011 . Influência do espaço vital de crescimento na altura e diâmetro de Pinus taeda L. Scientia Forestalis 39: 377-385.

Ladeira, B.C., Reis, G.G., Reis, M.G.F., Barros, N.F. 2001. Produção de biomassa de eucalipto sob três espaçamentos em uma seqüência de idade. Revista Árvore 25(1): 69-78.

Leles, P.S.S., Abaurre, G.W., Alonso, J.M., Nascimento, D.F., Lisboa, A.C. 2011 . Crescimento de espécies arbóreas sob diferentes espaçamentos em plantio de recomposição florestal. Scientia Forestalis 39: 231-239.

Lima, E.A. Silva, H.D., Lavoranti, O.J. 2011. Caracterização dendroenergética de árvores de Eucalyptus benthamii. Pesquisa Florestal Brasileira 31 (65): 09-17. 
Lopes, C.S.D., Nolasco, A.M., Tomazello Filho, M., Dias, C.T.S., Pansini, A. 2011. Estudo da massa especifica básica e da variação dimensional da madeira de três espécies de eucalipto para a indústria moveleira. Ciência Florestal 21 (2): 315322.

Mattos, B.D., Gatto, D.A., Stangerlin, D.M., Calegari, L., Melo, R.R., Santini, E.S. 2011 . Variação axial da densidade básica da madeira de três espécies de gimnospermas. Revista Brasileira de Ciências Agrárias 6(1): 121-126.

Oliveira, L.S., Costa, E.C., Cantarelli, E.C., Perrando, E.R., Pacheco, D.D.P. 2006. Ocorrência de Phaops thunbergi (Coleoptera: Curculionidae) em Acacia mearnsii De Wild. Ciência Rural 36(3): 971-972.

Quirino, W.F., Vale, A.T., Andrade, A.P.A., Abreu, V.L.S., Azevedo, A.C.S. 2005. Poder calorífico da madeira e de materiais ligno-celulósicos. Revista da Madeira 15(89): 100-106.

Roque, R.M., Ledzema, R.M. 2003. Efecto del espaciamiento en plantación sobre dos propiedades físicas de madera de teca a lo largo del fuste. Madera y Bosques 9(2): 15-27.

Sanquetta, C.R. Métodos de determinação de biomassa florestal. 2002. In: Sanquetta, C.R. (ed.). As florestas e o carbono. Curitiba, Brasil. p. 119 140.

Sanquetta, C.R., Behling, A., Corte, A.P.D., Simon, A., Pscheidt, H., Ruza, M.S., Mochiutti, S. 2014. Estoques de biomassa e carbono em povoamentos de acácia negra em diferentes idades no Rio Grande do Sul. Scientia Forestalis 42: 361-370.

Schumacher, M.V., Witschoreck, R., Calil, F.N. 2011 . Biomassa em povoamentos de Eucalyptus spp. de pequenas propriedades rurais em Vera Cruz, RS. Ciência Florestal 21: 17-22.

Silva, D.A. Caron, B.O., Behling, A., Souza. V.Q., Eloy, E. 2012. Ponto de amostragem ao longo do fuste para estimativa do poder calorífico da madeira. Ciência Rural 42(9): 1588-1595.

Silva, D.A., Müller, B.V., Kuiaski, E.C., Eloy, E., Behling, A., Colaço, C.M. 2015. Propriedades da madeira de Eucalyptus benthamii para produção de Energia. Pesquisa Florestal Brasileira 35(84): 481-485.

Trevisan, R., Haselein, C.R., Santini, E.J., Schneider, P.R., Menezes, L.F. 2007. Efeito da intensidade de desbaste nas características dendrométricas e tecnológicas da madeira de Eucalyptus grandis. Ciência Florestal 17(4): 377-387.

Trevisan, R., Eloy, E., Denardi, L., Haselein, C.R., Caron, B.O. 2012. Variação axial e efeito do desbaste na massa específica das árvores centrais de Eucalyptus grandis. Ciência Rural 42(2): 312-318.

Vale, A.T., Mourão, M.A., Leão, B.A.L. 2002. Qualificação e caracterização energética da madeira e casca de espécies do cerrado. Ciência Florestal 12(1): 71-80.

Vidaurre, G.B., Carneiro, A.C.O., Vital, B.R., Santos, R.C., Valle, M.L.A. 2012. Propriedades energéticas da madeira e do carvão de paricá (Schizolobium amazonicum). Revista Árvore 36(2): 365-371. 